\title{
Renewable diesel production from rapeseed oil with hydrothermal hydrogenation and subsequent decarboxylation
}

\author{
$\operatorname{AUTHOR}(S)$ :
}

Sugami, Yuitsu; Minami, Eiji; Saka, Shiro

\section{CITATION:}

Sugami, Yuitsu ...[et al]. Renewable diesel production from rapeseed oil with

hydrothermal hydrogenation and subsequent decarboxylation. Fuel 2016, 166: 376-381

\section{ISSUE DATE:}

2016-02

URL:

http://hdl.handle.net/2433/203653

\section{RIGHT:}

(c) 2015. This manuscript version is made available under the CC-BY-NC-ND 4.0 license

http://creativecommons.org/licenses/by-nc-nd/4.0/; The full-text file will be made open to the public on 1 February 2018 in accordance with publisher's 'Terms and Conditions for Self-Archiving'.; This is not the published version. Please cite only the published version.; この論文は出版社版でありません。引用の際には出版社版をご確認ご利用ください。 
Title:

Renewable diesel production from rapeseed oil with hydrothermal hydrogenation and subsequent decarboxylation

Authors: Yuitsu Sugami, Eiji Minami and Shiro Saka

Affiliation: Graduate School of Energy Science, Kyoto University, Japan

Address: Yoshida-honmachi, Sakyo-ku, Kyoto 606-8501, Japan

Tel/Fax: +81 (0) 757534738

E-mail: saka@energy.kyoto-u.ac.jp

Corresponding author: Shiro Saka

\section{Highlights}

- Hydrocarbon production from rapeseed oil was studied.

- The process consists of hydrolysis/hydrogenation and subsequent decarboxylation.

- The composition of the obtained hydrocarbons can be foreseen from raw material.

- The product meets the Japanese diesel standard by blending with fossil diesel. 


\section{Abstract}

2 Hydrocarbon (renewable diesel) production from rapeseed oil was studied with hydrothermal

3 hydrogenation and subsequent decarboxylation in a batch-type reaction vessel. An appropriate reaction condition for hydrothermal hydrogenation was found to be $270{ }^{\circ} \mathrm{C} / 5 \mathrm{MPa}\left(\mathrm{H}_{2}\right.$ pressure $)$ with water and

$5 \mathrm{Pd} / \mathrm{C}$ catalyst for $60 \mathrm{~min}$, under which triglycerides were simultaneously hydrolyzed and hydrogenated

6 into saturated fatty acids in a yield of $98.4 \mathrm{~mol} \%$. The obtained saturated fatty acids were then decarboxylated to hydrocarbons under the condition of $300{ }^{\circ} \mathrm{C} / 1 \mathrm{MPa}\left(\mathrm{H}_{2}\right.$ pressure $)$ with $\mathrm{Pd} / \mathrm{C}$ for 120

$8 \mathrm{~min}$ in a yield of $91.5 \mathrm{~mol} \%$ on rapeseed oil. In addition, the composition of the obtained hydrocarbons

9 corresponded nearly to that of the fatty acid in rapeseed oil. Such a result indicates that the composition

10 of hydrocarbons produced in this proposed process can be foreseen from fatty acid composition of the

11 feedstock triglycerides. By blending the obtained hydrocarbons from rapeseed oil with an adequate

12 amount of fossil diesel, the blended fuel could satisfy the specification standard of fossil diesel in

13 Japan.

\section{Keywords}

16 Renewable diesel; Plant oil; Hydrolysis; Hydrogenation; Decarboxylation 


\section{Introduction}

The fossil fuels are finite resources and their mass consumption has significant impacts on

our environment and society. For these reasons, fatty acid methyl ester (FAME) is being used as an

alternative diesel fuel produced by transesterification of triglyceride, a main component of plant oil,

with methanol. Because FAME is renewable fuel containing no aromatics and sulfur, it can reduce

exhaust emissions $[1,2]$. However, FAME has some drawbacks caused by the difference in chemical

structure from petroleum diesel, for example, corrosiveness against certain types of rubber and metal

[3] and poor oxidation stability due to unsaturated double bonds [1-4]. To overcome such drawbacks,

hydrocarbon productions from plant oils with the hydrotreating and catalytic cracking are being researched worldwide [5-19].

and $450{ }^{\circ} \mathrm{C}$ under the pressure between 4 and $15 \mathrm{MPa}$ with $\mathrm{H}_{2}$ and a catalyst [5-13]. As a catalyst, for

example, sulfided CoMo and NiMo supported on $\mathrm{SiO}_{2}, \mathrm{Al}_{2} \mathrm{O}_{3}, \mathrm{ZrO}_{2}, \mathrm{TiO}_{2}$ and zeolites were used [5-11].

Under the hydrotreating reaction, first, double bonds in fatty acid moieties of triglyceride are

hydrogenated into saturated C-C bonds, followed by the cleavage of ester linkages to produce one

molecule of propane and three molecules of saturated fatty acids $[6,12]$. The obtained saturated fatty

acids are then deoxidized into hydrocarbons having carbon numbers mainly between 15 and 18 through 
39

contributes to improving the cold-flow properties. In addition, $\mathrm{CO}, \mathrm{CO}_{2}, \mathrm{H}_{2} \mathrm{O}$ and propane are produced as byproducts [6].

On the other hand, the catalytic cracking of plant oils was usually carried out in the temperature range between 300 and $500{ }^{\circ} \mathrm{C}$ under atmospheric pressure with zeolites, $\mathrm{Al}_{2} \mathrm{O}_{3}$ and $\mathrm{MgO}$ as a catalyst [14-17], under which the thermal decomposition is predominant. First, triglycerides are decomposed to fatty acids, ketones, aldehydes and esters [18]. These products undergo secondary cracking to form short and long chain paraffins and olefins with $\mathrm{CO}, \mathrm{CO}_{2}, \mathrm{H}_{2} \mathrm{O}$ and alcohols by breaking $\mathrm{C}-\mathrm{O}$ and $\mathrm{C}-\mathrm{C}$ bonds via decarboxylation and decarbonylation. However, this process makes various hydrocarbons having wide range of carbon numbers with olefins and aromatics.

After all, the selectivity of the products is not so high with the conventional hydrotreating and catalytic cracking mentioned above. It should be caused by the presence of unsaturated fatty acid moieties, which leads to various side reactions. Actually, Dos Anjos et al. studied the catalytic cracking of prehydrogenated soybean oil as well as crude one, reporting that prehydrogenated oil yielded essentially pure hydrocarbon products, while crude oil yielded a mixture of oxygen-containing products and the lower molecular weight hydrocarbons [20].

In this study, therefore, hydrocarbon production from plant oil was studied through two-step reaction with hydrolysis and subsequent decarboxylation. During the hydrolysis step, hydrogenation was simultaneously conducted to produce stable saturated fatty acids, which may suppress undesirable side reactions during subsequent decarboxylation $[19,20]$. In the literature [5-21], furthermore, an 
organic solvent such as $n$-dodecane was usually added to enhance the fluidity of the reactants and to

avoid the deactivation of catalyst, even though only a few studies without any solvent can be found [19, renewable diesel.

\section{Materials and Methods}

\subsection{Experimental procedures}

Fig.1 shows the schematic diagram of the saturated hydrocarbon (renewable diesel)

production process in this study via saturated fatty acids from rapeseed oil. Prior to the experiment,

treated in hot-compressed water with $\mathrm{H}_{2}$ gas and $\mathrm{Pd} / \mathrm{C}$ catalyst for hydrolysis and hydrogenation to 


\subsubsection{Hydrolysis coupled with hydrogenation (Hydrolysis/hydrogenation)}

A batch-type reaction vessel (inner volume: $5.0 \mathrm{ml}$ ) made of Inconel-625 [23] was used for the reaction. One gram of rapeseed oil and $1.0-3.0 \mathrm{~g}$ of ion-exchanged water were placed into the reaction vessel with $0.05 \mathrm{~g}$ of $\mathrm{Pd} / \mathrm{C}$. Hastelloy balls (total volume: $0.2 \mathrm{ml}$ ) were also placed into the vessel to agitate the mixture efficiently. After the vessel was sealed, the inside of the vessel was purged and pressurized to $5 \mathrm{MPa}$ with $\mathrm{H}_{2}$ gas using a gas-supplying system. The hydrolysis coupled with hydrogenation (hydrolysis/hydrogenation) reaction was then conducted by immersing the vessel into a molten salt bath preheated at $270{ }^{\circ} \mathrm{C}$, which is the optimum temperature for hydrolysis of triglycerides found in previous works $[24,25]$. The reaction vessel was swung from side to side to agitate the mixture during the reaction. After a designated treatment time, the vessel was moved into a water bath to quench the reaction. The obtained reaction mixture dissolved in tetrahydrofuran (THF, specially prepared reagent grade, Nacalai Tesque, Inc.) was, then, taken out from the vessel, sonicated for $30 \mathrm{~min}$, and the catalyst was removed with a filter paper in a micropore of $0.45 \mu \mathrm{m}$ (Merck Millipore Co.). The products were, then, warmed up in a water bath at $70{ }^{\circ} \mathrm{C}$ for $30 \mathrm{~min}$ and separated into THF and water phases. By removing THF from the THF phase with a rotary vacuum evaporator, the products of the

hydrolysis/hydrogenation reaction were collected and their yield was determined. 


\subsubsection{Decarboxylation}

For subsequent decarboxylation, approximately $0.9 \mathrm{~g}$ of the obtained saturated fatty acids and

$0.05-0.45 \mathrm{~g}$ of $\mathrm{Pd} / \mathrm{C}$ were placed into the $5 \mathrm{ml}$ reaction vessel with Hastelloy balls. The inside of the

reaction vessel was then purged and pressurized with $\mathrm{N}_{2}$ or $\mathrm{H}_{2}$ gas to be $1 \mathrm{MPa}$ which is a favorable

pressure for decarboxylation reaction [26]. The decarboxylation was, then, conducted with the molten

salt bath at $300{ }^{\circ} \mathrm{C}$ for $120 \mathrm{~min}$, which is an appropriate condition reported by Lestari et al. [27], and

products dissolved in THF were taken out from the vessel, sonicated for $30 \mathrm{~min}$, and the catalyst was

obtained to determine its yield. To clarify the decarboxylation reaction of the saturated fatty acid,

palmitic acid, stearic acid and arachidic acid (all being guaranteed reagent grade from Nacalai Tesque,

Inc.) were also studied.

\subsection{Analytical methods}

The fatty acid composition of rapeseed oil used in this work was determined in accordance

with the Japan Oil Chemists' Society standard method [28]. The products, obtained from

hydrolysis/hydrogenation and subsequent decarboxylation, were analyzed by gel permeation 
111 RID-10A) and high performance liquid chromatography (HPLC, column: Cadenza CD-C18 (Imtakt

112 Co.), oven temperature: $40{ }^{\circ} \mathrm{C}$, mobile phase: methanol, flow-rate: $1.0 \mathrm{ml} / \mathrm{min}$, detector: RID-10A). By

113 the GPC analysis, the obtained products from hydrolysis/hydrogenation can be separated into four

114 peaks, which correspond to the groups of triglycerides, diglycerides, monoglycerides and fatty acids.

115 The amount of each group was quantified based on the corresponding peak area, using tristearin,

116 1,3-distearin, 1-monostearin (all being >99\% grade from Olbracht Serdary Research Laboratories) and

117 stearic acid (guaranteed reagent grade from Nacalai Tesque, Inc.) as calibration standards. The HPLC

118 analysis, by which fatty acids can be separated into single ones, was then conducted to quantify the

119 amount of each fatty acid. In this way, the yields of the products were determined in mol\%. The

120 obtained product from the decarboxylation reaction was also quantified in a similar manner.

The fuel properties of the renewable diesel were evaluated for flash point, pour point, cold

122 filter plugging point, kinematic viscosity and density as in Table 2. In addition, the renewable diesel

123 was blended in various ratios with fossil diesel (\#1 diesel of the Japanese Industrial Standard (JIS),

124 purchased from SHOWA SHELL SEKIYU K.K.), and their fuel properties were also evaluated. The

125 density was determined in accordance with the ASTM International's standard ASTM D1298 [29],

126 while the flush point, pour point, cold filter plugging point and kinematic viscosity were measured by

127 the automated Pensky-Martens closed cup flush point tester (APM-7), the mini pour point tester

128 (MPC-102), the automated cold filter plugging point tester (AFP-102) and the automatic kinematic

viscosity measuring system (AKV-201), respectively. All of these measuring systems were made by 


\section{Results and Discussion}

after hydrolysis/hydrogenation and subsequent decarboxylation. Rapeseed oil used in this study is described in the following subsections.

\subsection{Hydrolysis/hydrogenation}

Figure 2(a) and 2(b) show respectively GPC and HPLC chromatograms of the obtained

products through hydrolysis/hydrogenation reaction from $0.9 \mathrm{~g}$ of rapeseed oil as treated at $270{ }^{\circ} \mathrm{C} / 5$

MPa $\left(\mathrm{H}_{2}\right)$ with $3.0 \mathrm{~g}$ of water and $0.05 \mathrm{~g}$ of Pd/C. In Fig. 2(a), triglycerides (TG) in rapeseed oil are

decreasing as reaction time is prolonged. For 20 and 40 min treatments, diglycerides (DG) and

monoglycerides (MG) are being observed as intermediate compounds, but almost all of them also

disappear after $60 \mathrm{~min}$. Meanwhile, fatty acids (FA) are increasing with reaction time until $60 \mathrm{~min}$ 
149 converted into saturated ones through hydrogenation, because saturated fatty acids have a slightly

150 shorter retention time than unsaturated ones on the GPC column used in this study. Actually, only

151 saturated fatty acids such as palmitic $\left(\mathrm{C}_{16: 0}\right)$, stearic $\left(\mathrm{C}_{18: 0}\right)$ and arachidic $\left(\mathrm{C}_{20: 0}\right)$ acids can be found after

15220 min treatment by HPLC analysis as shown in Fig. 2(b). It indicates that hydrogenation is faster than

153 hydrolysis and completed within $20 \mathrm{~min}$.

From the above, an appropriate reaction time for hydrolysis/hydrogenation was found to be

$60 \mathrm{~min}$ at the given conditions. Based on the HPLC and GPC analyses, the yield of the products from

rapeseed oil was determined as shown in Table 1. Triglycerides in rapeseed oil were converted into

saturated fatty acids and their yield was summed up to be $96.1(=4.5+89.7+1.9)$ mol\%. In addition,

$2.3 \mathrm{~mol} \%$ of glycerides still remained as intermediate compounds. Finally, the total yield of fatty acids

and glycerides was 98.4 mol\% and any other products were not observed in the HPLC chart. In

addition, no gaseous products were produced and saturated fatty acids are stable under the given

condition. Thus, no product decomposition would be occurred. Therefore, the rest of $1.6 \mathrm{~mol} \%$ would

probably be lost through the purification steps. By excluding the lost portion, the molar ratio upon the

obtained products basis was shown in parenthesis in Table 1. As a result, the molar ratio of the obtained

saturated fatty acids $\left(\mathrm{C}_{16: 0}: \mathrm{C}_{18: 0}: \mathrm{C}_{20: 0}=4.6: 91.2: 1.9\right)$ is close to the fatty acid composition of

rapeseed oil $\left(\mathrm{C}_{16: 0}+\mathrm{C}_{16: 1}: \mathrm{C}_{18: 0}+\mathrm{C}_{18: 1}+\mathrm{C}_{18: 2}+\mathrm{C}_{18: 3}: \mathrm{C}_{20: 0}+\mathrm{C}_{20: 1}=4.5: 94.0: 1.5\right)$. It means that the 
with $3.0 \mathrm{~g}$ of water. Thus, the weight ratio of water/rapeseed oil was 3.0/1.0 for Table 1 and Fig. 2.

169 However, when its ratio decreased from 3.0/1.0 to 1.0/1.0, the yield of saturated fatty acids decreased

from $97.7 \mathrm{~mol} \%$ to $77.2 \mathrm{~mol} \%$ due to the insufficient hydrolysis of glycerides and fatty acids under the

same reaction condition. From these results, it was concluded that an appropriate

hydrolysis/hydrogenation condition is $270{ }^{\circ} \mathrm{C} / 5 \mathrm{MPa}\left(\mathrm{H}_{2}\right)$ with $3.0 \mathrm{~g}$ of water and $0.05 \mathrm{~g}$ of $\mathrm{Pd} / \mathrm{C}$ for

$1.0 \mathrm{~g}$ of rapeseed oil.

\subsection{Decarboxylation}

As a preliminary experiment, the effect of atmospheric gas $\left(\mathrm{N}_{2}\right.$ or $\left.\mathrm{H}_{2}\right)$ was investigated on

decarboxylation reaction by using stearic acid as a model compound. When $\mathrm{N}_{2}$ gas was used, no

conversion was observed at the conditions of $300{ }^{\circ} \mathrm{C} / 1 \mathrm{MPa} / 0.05 \mathrm{~g}$ of $\mathrm{Pd} / \mathrm{C}$ for $120 \mathrm{~min}$. In the case of

$\mathrm{H}_{2}$ gas, on the other hand, $16.3 \mathrm{~mol} \%$ of $n$-heptadecane was obtained at the same condition. Although

$\mathrm{H}_{2}$ is not essentially required by the decarboxylation reaction, it keeps the catalyst activity $[32,33]$.

Actually, some researchers have reported that an efficient decarboxylation was observed in the presence

of $\mathrm{H}_{2}[19,33,34]$. Therefore, $\mathrm{H}_{2}$ gas was used in the following experiments. 
conversions were found respectively to be 16.3 and $26.1 \mathrm{~mol} \%$ from stearic acid into $n$-heptadecane.

On the other hand, $90.3 \mathrm{~mol} \%$ of $n$-heptadecane was achieved with $0.45 \mathrm{~g}$ of $\mathrm{Pd} / \mathrm{C}$. Therefore, it was

concluded that $0.45 \mathrm{~g}$ of $\mathrm{Pd} / \mathrm{C}$ is required for the efficient decarboxylation of $0.9 \mathrm{~g}$ of fatty acid at the

given conditions. In general, decarboxylation of fatty acids proceeds in three phases, gaseous $\mathrm{H}_{2}$, liquid reason why such a large amount of $\mathrm{Pd} / \mathrm{C}$ catalyst was needed. Therefore, an effective agitation would be required to reduce the amount of the catalyst. acids by hydrolysis/hydrogenation and hydrocarbons after decarboxylation. Triglycerides in rapeseed oil are composed of various fatty acids, thus many peaks are found in Fig.3. However, these peaks are converted mainly into three peaks of saturated fatty acids, palmitic $\left(\mathrm{C}_{16: 0}\right)$, stearic $\left(\mathrm{C}_{18: 0}\right)$ and arachidic

$199\left(\mathrm{C}_{20: 0}\right)$ acids, by hydrolysis/hydrogenation of triglycerides. These saturated fatty acids are then converted into $n$-pentadecane $\left(\mathrm{C}_{15} \mathrm{H}_{32}\right), n$-heptadecane $\left(\mathrm{C}_{17} \mathrm{H}_{36}\right)$ and $n$-nonadecane $\left(\mathrm{C}_{19} \mathrm{H}_{40}\right)$, respectively, by subsequent decarboxylation. Therefore, the obtained renewable diesel from rapeseed oil consists of these three kinds of saturated hydrocarbons. 
205 Since hydrocarbons are stable enough under the given condition, no decomposition of the products can

206 be occurred. Therefore, the rest of $8.5 \mathrm{~mol} \%$ would probably be lost through the purification steps. The

207 loss of the products would be caused by using a large amount of catalyst, on which the products were

208 adsorbed. The molar ratio upon the obtained hydrocarbon basis was shown in parenthesis in Table 1. As

209 a result, the molar ratio of obtained $n$-pentadecane, $n$-heptadecane and $n$-nonadecane was found out to

210 be $4.5: 93.6: 1.9$. This molar ratio is nearly close to the one of saturated fatty acids $\left(\mathrm{C}_{16: 0}: \mathrm{C}_{18: 0}: \mathrm{C}_{20: 0}\right.$

$211=4.6: 91.2: 1.9$ in Table 1) obtained after hydrolysis/hydrogenation. Therefore, these saturated fatty

212 acids seem to be selectively converted without any side reaction into the corresponding hydrocarbons

213 through decarboxylation. In case of unsaturated fatty acids, however, various side reactions such as

214 hydrogenation, dehydrogenation, cyclization, ketonization, dimerization and cracking have been

215 reported to occur concurrently due to the unstable double bonds present $[35,36]$, which lead to

216 decrease the degree of the specific production of hydrocarbons. Therefore, unsaturated fatty acids

217 should be converted into saturated ones before decarboxylation to maintain its high selectivity. For this

218 specificity, the process shown in Fig. 1 is appropriate and promising.

After hydrolysis/hydrogenation, $2.3 \mathrm{~mol} \%$ of glycerides such as monoglycerides and

diglycerides still remain as shown in Table 1. However, these intermediate compounds are disappeared

after decarboxylation, and converted into hydrocarbons. Actually, when 1-monostearin was treated at

the same condition, it was converted into $n$-heptadecane by decarboxylation treatment with $\mathrm{H}_{2}$ gas and

$\mathrm{Pd} / \mathrm{C}$ catalyst even though the reactivity was slightly low, compared with saturated fatty acids. 
224 Therefore, the remaining glycerides must be converted to saturated fatty acids during decarboxylation

treatment.

The iodine and acid values of the obtained hydrocarbons from rapeseed oil were evaluated

and found out to be zero. This means that the obtained products have neither double bonds nor fatty

acids. It is, therefore, evident that hydrogenation and decarboxylation reactions are successfully

completed during the process.

\subsection{Fuel properties of saturated hydrocarbons}

It is very important to evaluate the fuel properties of the renewable diesel. However, the

prepared renewable diesel is not sufficient in amount to test the fuel properties. As in Table 1, it

consists of the saturated linear hydrocarbons of $n$-pentadecane, $n$-heptadecane and $n$-nonadecane in a

molar ratio of $4.5: 93.6: 1.9$. In addition, it was confirmed that such a mixture does not contain any

contaminants. Therefore, a mixture of these three kinds of hydrocarbons was prepared from their

chemicals purchased as the renewable diesel and evaluated for the fuel properties.

diesel in various ratios. In case of $100 \mathrm{vol} \%$ renewable diesel, it has a higher flash point than that of the

diesel in Japan (JIS K2204) [37]. Such a property should be originated from $n$-heptadecane, a main 
diesel. In addition, the values of kinematic viscosity and density also satisfy the requirements for the

244 Japanese diesel standard. These values are also close to the ones of $n$-heptadecane. On the other hand,

245 the cold-flow properties such as pour point and cold filter plugging point are poor due to the presence

246 of saturated linear hydrocarbons, because these have relatively high melting points, especially in case

247 of $n$-heptadecane. Therefore, the cold-flow properties should be improved to meet the fossil diesel

248 standard. Blending the renewable diesel with fossil one is a simple way for this purpose. In case of 20

249 vol\% renewable diesel, as shown in Table 2, the pour point and cold filter plugging point are improved,

250 and thus, it can satisfy the requirements for the fuel standard. However, when the ratio of renewable

251 diesel is increased to be $30 \mathrm{vol} \%$, the pour point exceeds the limit of the standard. From such a reason,

252 the blending ratio would be limited up to around $20 \mathrm{vol} \%$ to meet all requirements of the specification

253 standard in Table 2. This further indicates that the obtained hydrocarbons through this process can be

254 used as renewable diesel by blending with fossil diesel.

\section{Concluding Remarks}

To produce hydrocarbons from plant oil as renewable diesel fuel, the conventional

hydrotreating and catalytic cracking processes are not really specific for the products selectivity due to

unsaturated double bonds. In this study, therefore, the process composed of hydrolysis/hydrogenation

and subsequent decarboxylation was proposed. In the first treatment, triglycerides in rapeseed oil were 
hydrogenolysis under the presence of $\mathrm{Pd} / \mathrm{C}$ catalyst and $\mathrm{H}_{2}$ gas. In the second treatment, the obtained

saturated fatty acids were decarboxylated into the corresponding hydrocarbons under the presence of

$264 \mathrm{Pd} / \mathrm{C}$. In this process, unsaturated double bonds in fatty acid moieties, which lead to various side reactions, were hydrogenated into saturated ones prior to the second treatment. Therefore, the selective conversion was achieved by this two-step treatment without any side reaction. As a result, the composition of the obtained hydrocarbons corresponded to the fatty acid composition of rapeseed oil. because saturated linear hydrocarbons have relatively high melting points, whereas other properties satisfy the requirements, a blend of renewable diesel with fossil diesel was found out to weaken the the fossil fuel.

\section{Acknowledgement}




\section{References}

281

[1] Krawcyk T. BIODIESEL: alternative fuel makes inroads but hurdles remain. Inform 1996;7(8):801-15

[2] Knothe G, Sharp CA, Ryan TW. Exhaust emissions of biodiesel, petrodiesel, neat methyl esters, and alkanes in a new technology engine. Energ Fuel 2006;20(20):403-8.

[3] Haseeb ASMA, Fazal MA, Jahirul MI, Masjuki HH. Compatibility of automotive materials in biodiesel: A review. Fuel 2011;90(3):922-31.

[4] Moser BR. Biodiesel production, properties, and feedstocks, In Vitro Cell Dev-Pl 2009;45(3):229-66.

[5] Monnier J, Tourigny G, Soveran DW, Alfred Wong, Hogan EN, Stumborg M. Conversion of biomass feedstock to diesel fuel additive, US patent 5705722, 1998.

[6] Satyarthi JK., Chiranjeevi T, Gokak DT, Viswanathan PS. An overview of catalytic conversion of vegetable oils/fats into middle distillate. Catal Sci Technol 2013;3(1):70-80.

[7] Gong S, Shinozaki A, Shi M, Qian EW. Hydrotreating of Jatropha Oil over Alumina Based Catalysts. Energ Fuel 2012;26(4):2394-9.

[8] Kubička D, Kaluža L. Deoxygenation of vegetable oils over sulfided Ni, Mo and NiMo catalysts. Appl Catal A: Gen 2010;372(2):199-208.

[9] Madsen AT, Ahmed EH, Christensen CH, Fehrmann R, Riisager A. Hydrodeoxygenation of waste fat for diesel production: Study on model feed with Pt/alumina catalyst. Fuel 2011;90(11):3433-8. 
[10] Krár M, Kovács S, Kalló D, Hancsók J. Fuel purpose hydrotreating of sunflower oil on $\mathrm{CoMo} / \mathrm{Al}_{2} \mathrm{O}_{3}$ catalyst. Bioresource Technol 2010;101(23):9287-93.

[11] Huber GW, O'Conno P, Corma A. Processing biomass in conventional oil refineries: Production of high quality diesel by hydrotreating vegetable oils in heavy vacuum oil mixtures. Appl Catal A: Gen 2007;329(1):120-9.

[12] Watanabe M, Iida T, Inomata H. Decomposition of a long chain saturated fatty acid with some additives in hot compressed water. Energ Convers Manage 2006;47(18-19):3344-50.

[13] Mikulec J, Cvengroš J, Joríková L', Banič M, Kleinová A. Second generation diesel fuel from renewable sources. J Clean Prod 2010;18(9):917-26.

[14] Tani H, Shimouchi M, Haga H, Fujimoto K. Development of Direct Production Process of Diesel Fuel from Vegetable Oils. J Jpn Inst Energy 2011;90:466-70.

[15] Maher KD, Bressler DC. Pyrolysis of triglyceride materials for the production of renewable fuels and chemicals. Bioresource Technol 2007;98(12):2351-68.

[16] Rao KVC. Production of hydrocarbons by thermolysis of vegetable oils. US patent 4102938 A, 1978.

314 [17] Twaiq FA, Zabidi NAM, Bhatia S. Catalytic Conversion of Palm Oil to Hydrocarbons: Performance of Various Zeolite Catalysts. Ind Eng Chem Res 1999;38(9):3230-7.

[18] Taufiqurrahmi N, Bhatia S. Catalytic cracking of edible and non-edible oils for the production of biofuels. Energy Environ Sci 2011;4:1087-112. 
[19] Snåre M, Kubičková I, Mäki-Arvela $P$, Chichova D, Eränen K, Murzin DY. Catalytic deoxygenation of unsaturated renewable feedstocks for production of diesel fuel hydrocarbons. Fuel 2008;87(6):933-45.

[20] Dos Anjos JRS, Gonzalez WDA, Lam YL, Frety R. Catalytic decomposition of vegetable oil. Appl Catal 1983;5(3):299-308.

[21] Wang WC, Thapaliya N, Campos A, Stikeleather LF, Roberts WL. Hydrocarbon fuels from vegetable oils via hydrolysis and thermo-catalytic decarboxylation. Fuel 2012;95:622-9.

[22] Theilgaard MA, Rosmyslowicz B, Mäki-Arvela P, Simakova IL, Eränen K, Murzin DY, Fehrmann, 2013;56(9) 714-24.

[23] Saka S, Dadan K. Biodiesel fuel from rapeseed oil as prepared in supercritical methanol. Fuel 2001;80:225-31.

[24] Kusdiana D, Saka S. Two-Step Preparation for Catalyst-Free Biodiesel Fuel Production. Appl Biochem Biotech 2004;115(1-3):781-91.

[25] Minami E, Saka S. Kinetics of hydrolysis and methyl esterification for biodiesel production in two-step supercritical methanol process. Fuel 2006;85(17-18):2479-83. 
336

[27] Lestari S, Simakova I, Tokarev A, Mäki-Arvela P, Eränen K, Murzin DY. Synthesis of Biodiesel via Deoxygenation of Stearic Acid over Supported Pd/C Catalyst. Catal Lett 2008;122:247-51.

[28] Standard Methods for the Analysis of Fats, Oils and Related Materials, 2.4.2.2-2013, Fatty acids composition (FID temperature programmed gas chromatography), Japan Oil Chemists' Society, Tokyo, 2013.

[29] ASTM D1298-99 Standard test method for density, or API gravity of crude petroleum and liquid petroleum prducts by hydrometer method.

[30] ASTM D974-06 Standard Test Method for Acid and Base number by color-indicator titration.

[31] ASTM D1959-97 Standard test method for iodine value of drying oils and fatty acids.

[32] Maier W, Roth W, Thies I, van Ragué Schleyer P. Gas phase decarboxylation of carboxylic acids. Chem Ber 1982;115:808-812.

[33] Mäki-Arvela P, Kubičková I, Snåre M, Eränen K, Murzin DY. Catalytic deoxygenation of fatty acids and their derivatives. Energ Fuel 2007;21:30-41.

[34] Kubičková I, Snåre M, Eränen K, Mäki-Arvela P, Murzin DY. Hydrocarbons for diesel fuel via decarboxylation of vegetable oils. Catal Today 2005;106:197-200.

[35] Simakova I, Rozmysłowicz B, Simakova O, Mäki-Arvela P, Simakov A, Murzin DY. Catalytic Deoxygenation of C18 Fatty Acids Over Mesoporous Pd/C Catalyst for Synthesis of Biofuels. Top Catal 2011;54(8-9):460-6. 
354 [36] Snåre M, Kubičková I, Mäki-Arvela P, Eränen K, Murzin DY. Heterogeneous Catalytic

Deoxygenation of Stearic Acid for Production of Biodiesel. Ind Eng Chem Res 2006;45(16):5708-15.

[37] JIS K2204, Japanese industrial standards committee. Diesel fuel; 2007 [in Japanese]. 


\section{List of figures}

359

360 Figure 1: Schematic diagram of the saturated hydrocarbon production process via saturated fatty acids

361 from rapeseed oil.

362

363

Figure 2: GPC (a) and HPLC (b) chromatograms of the obtained saturated fatty acids by

364 hydrolysis/hydrogenation from rapeseed oil at $270{ }^{\circ} \mathrm{C} / 5 \mathrm{MPa}\left(\mathrm{H}_{2}\right)$ with $3.0 \mathrm{~g}$ of water and $0.05 \mathrm{~g}$ of

$365 \mathrm{Pd} / \mathrm{C}$.

366

367 Figure 3: HPLC chromatograms of rapeseed oil, the obtained saturated fatty acids by

368 hydrolysis/hydrogenation $\left(270{ }^{\circ} \mathrm{C} / 5 \mathrm{MPa}(\mathrm{H} 2)\right.$ with $3.0 \mathrm{~g}$ of water and $0.05 \mathrm{~g}$ of $\mathrm{Pd} / \mathrm{C}$ for $\left.60 \mathrm{~min}\right)$ and

369 the saturated hydrocarbons by decarboxylation $\left(300{ }^{\circ} \mathrm{C} / 1 \mathrm{MPa}\left(\mathrm{H}_{2}\right)\right.$ with $0.45 \mathrm{~g} \mathrm{Pd} / \mathrm{C}$ for $\left.120 \mathrm{~min}\right)$. 


\section{$370 \quad$ List of tables}

371

372 Table 1: Fatty acid composition of rapeseed oil, the obtained saturated fatty acids by

373 hydrolysis/hydrogenation and saturated hydrocarbons by decarboxylation.

375 Table 2: The fuel properties of renewable diesel blended with fossil diesel in various ratios compared

376 with Japanese \#1 diesel standard (JIS K2204) [37]. 


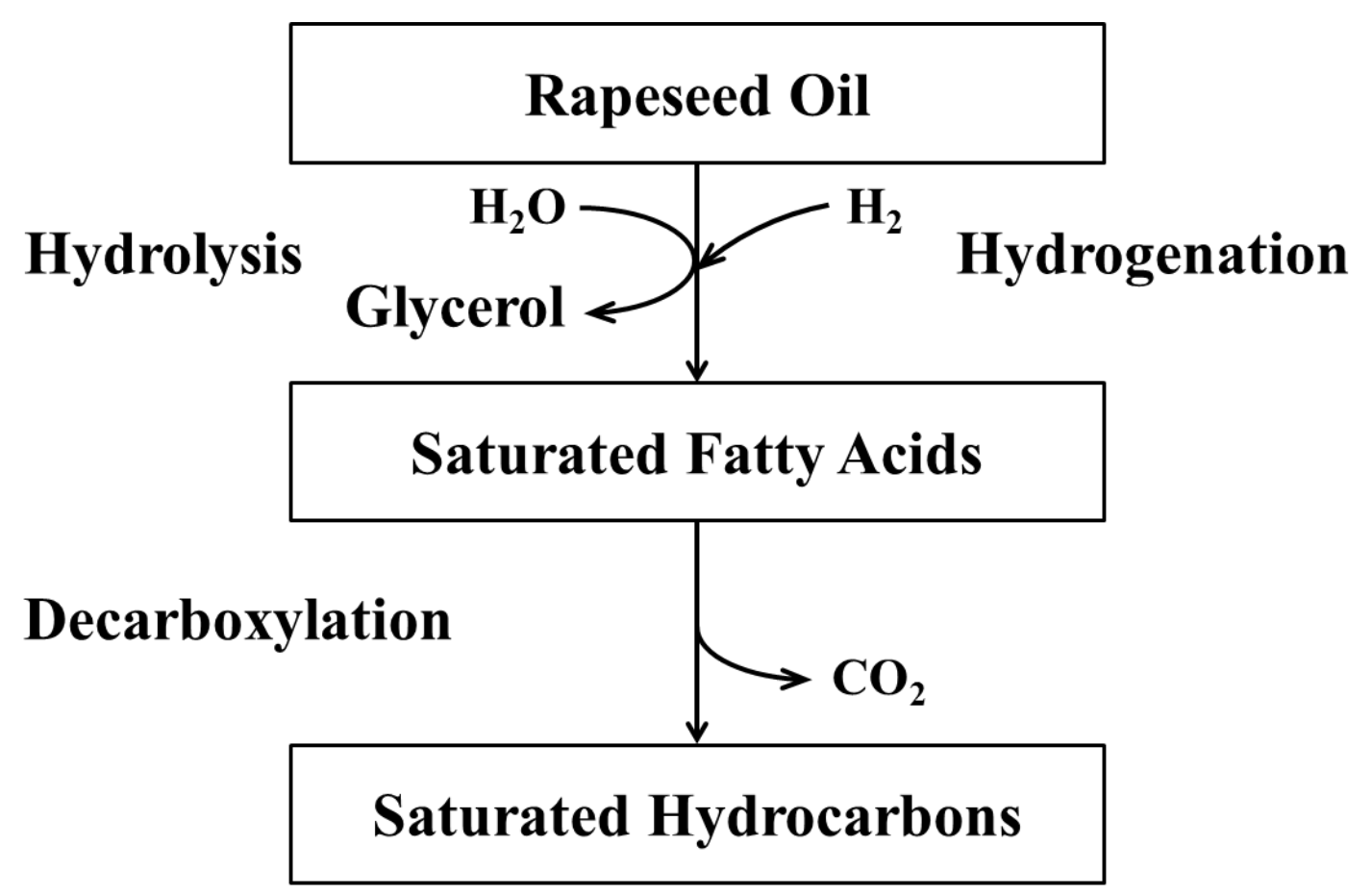

Fuel

Figure 1 

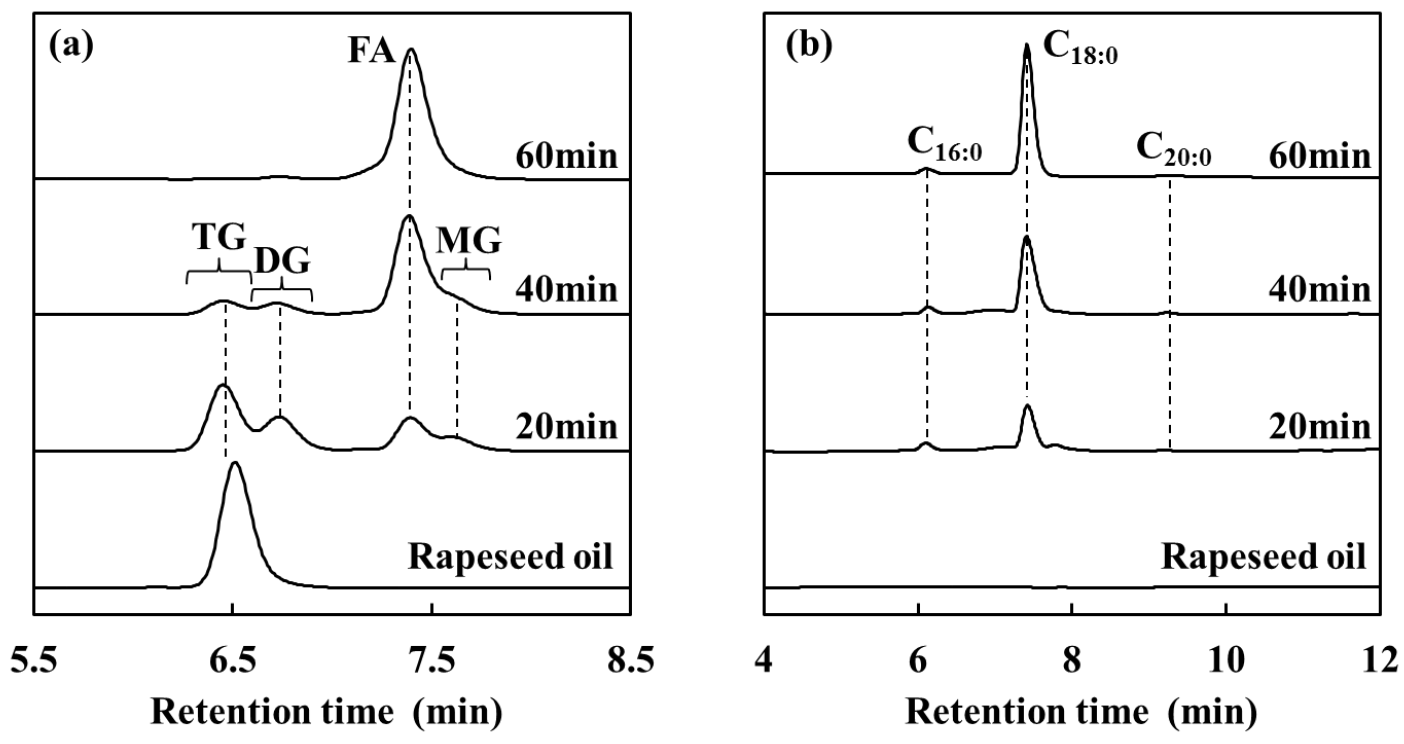

Fuel

Figure 2 


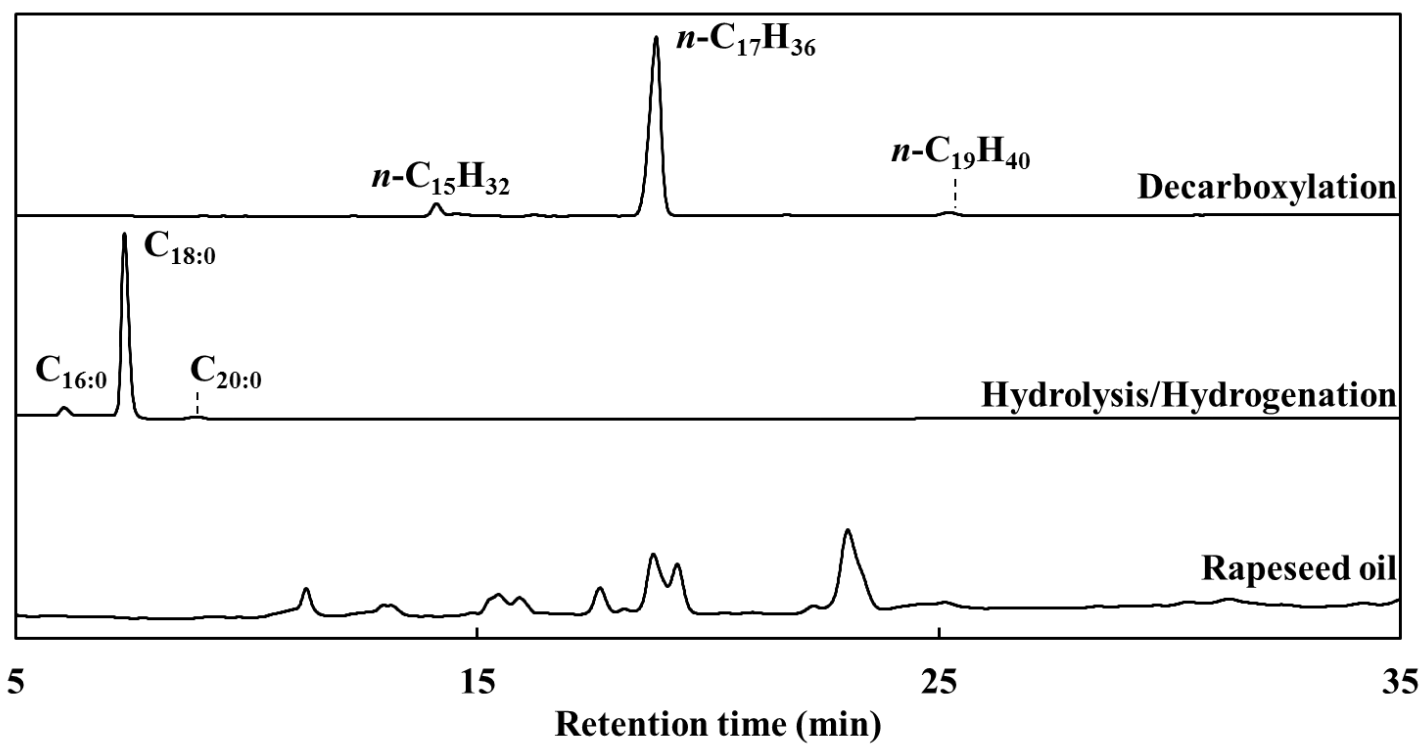

Fuel

Figure 3 
Table 1: Fatty acid composition of rapeseed oil, the obtained saturated fatty acids by hydrolysis/hydrogenation and saturated hydrocarbons by decarboxylation.

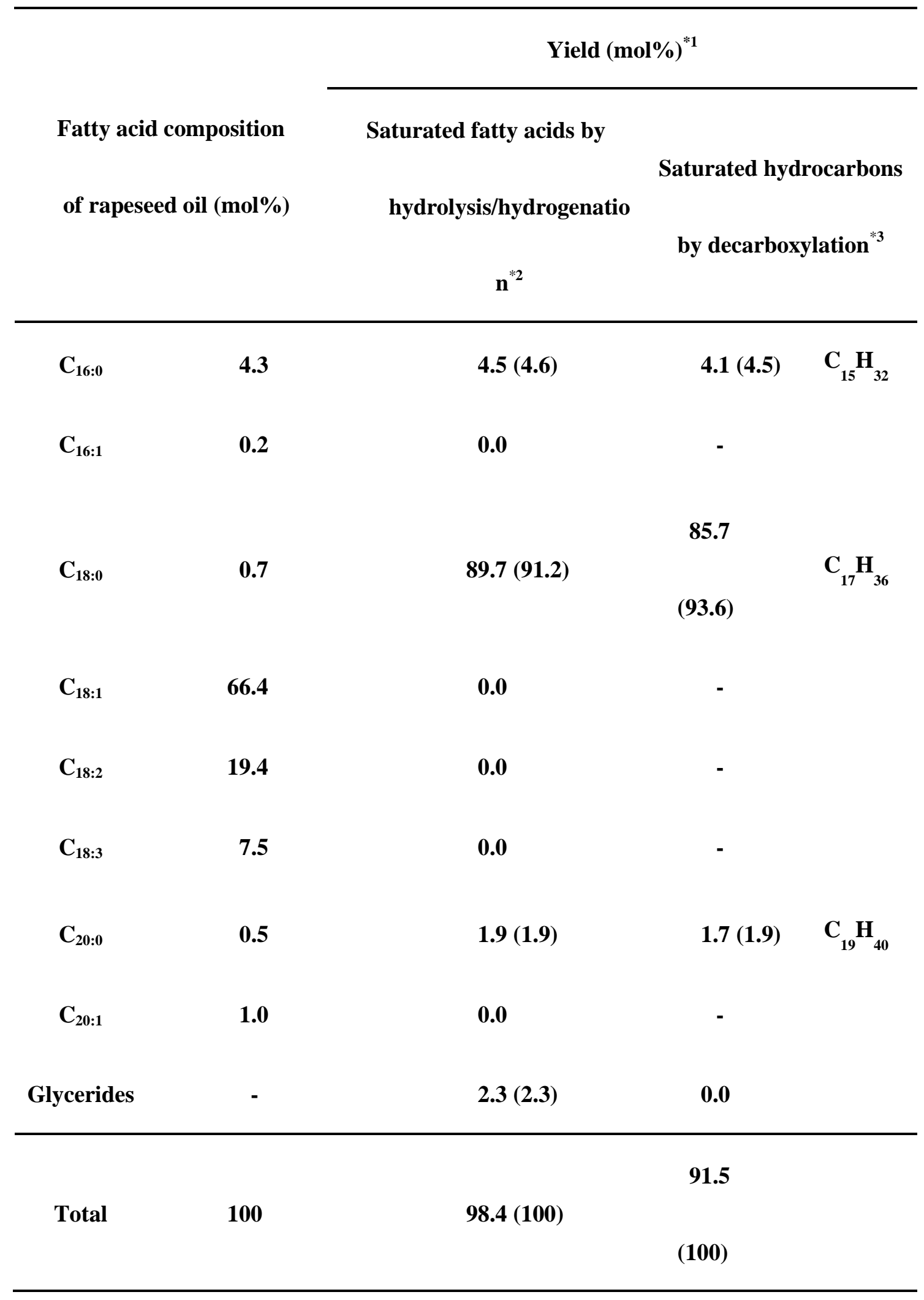


*1: The values in parenthesis indicate the mol\% on the total yield basis of rapeseed oil.

*2: $270{ }^{\circ} \mathrm{C} / 5 \mathrm{MPa}\left(\mathrm{H}_{2}\right)$ with $3.0 \mathrm{~g}$ of water and $0.05 \mathrm{~g}$ of $\mathrm{Pd} / \mathrm{C}$ for $60 \mathrm{~min}$

*3: $300^{\circ} \mathrm{C} / 1 \mathrm{MPa}\left(\mathrm{H}_{2}\right)$ with $0.45 \mathrm{~g} \mathrm{Pd} / \mathrm{C}$ for $120 \mathrm{~min}$

Table 2: The fuel properties of renewable diesel blended with fossil diesel in various ratios compared

with Japanese \#1 diesel standard (JIS K2204) [37].

\begin{tabular}{|c|c|c|c|c|c|c|}
\hline \multirow{3}{*}{ Property } & \multicolumn{5}{|c|}{ Ratio of renewable diesel $^{* 1}$} & \multirow{3}{*}{$\begin{array}{l}\text { \#1 diesel } \\
\text { standard }\end{array}$} \\
\hline & \multicolumn{5}{|c|}{ to \#1 fossil diesel (vol\%) } & \\
\hline & 100 & 30 & 20 & 5 & $\mathbf{0}^{* 2}$ & \\
\hline Flash point $\left({ }^{\circ} \mathrm{C}\right)$ & 153 & 75.0 & 69.5 & 64.5 & 63.5 & $\geqq \mathbf{5 0}$ \\
\hline Pour point $\left({ }^{\circ} \mathrm{C}\right)$ & 20 & 3.0 & -2.5 & -7.0 & -8.0 & $\leqq-2.5$ \\
\hline Cold filter plugging point $\left({ }^{\circ} \mathrm{C}\right)$ & 22 & -2.0 & -6.0 & -3.0 & -5.0 & $\leqq-1$ \\
\hline Kinematic viscosity at $30^{\circ} \mathrm{C}\left(\mathrm{mm}^{2} / \mathrm{s}\right)$ & 4.5 & 3.7 & 3.6 & 3.6 & 3.5 & $\geqq 2.7$ \\
\hline Density at $15^{\circ} \mathrm{C}\left(\mathrm{g} / \mathrm{cm}^{3}\right)$ & 0.77 & 0.82 & 0.83 & 0.83 & $\mathbf{0 . 8 3}$ & $\leqq 0.86$ \\
\hline
\end{tabular}

*1: The renewable diesel is prepared by mixing pure hydrocarbons with the same molar ratio as in Table 1.

*2: Renewable diesel 0 vol\% corresponds to fossil diesel $100 \mathrm{vol} \%$. 